\title{
Historical Literacy as Strengthening Character Education
}

\author{
Nadia Ramona ${ }^{1, *}$ Nana Supriatna ${ }^{2}$ \\ ${ }^{1,2}$ History Education Study Program, School of Postgraduate Universitas Pendidikan Indonesia, West Java \\ 40154, Indonesia \\ *Corresponding author. Email: nadiararamona@gmail.com.
}

\begin{abstract}
This article aims to describe the role of historical literacy through character biographies in strengthening character education. Moral decadence is an urgent issue that must be addressed, especially during the Covid-19 pandemic, houses are transformed into schools which make literacy and character are urgently needed. The low ability of historical literacy causes a decline in character, just like the rural children in Bayang, West Sumatera. The Covid-19 pandemic has intensified the ability to digitize in the learning process demanded by virtual learning even in rural areas. Digitalization as a new form of habit for rural children causes them to be addicted to games and social media by gathering in "Pondok Mojok" because they have stable internet access there. Strengthening character education can be achieved if it is supported by creative pedagogy which can be developed by building historical literacy skills of students through character biographies. This is what underlies the researcher to change the "Pondok Mojok" into "Pondok Literasi" to activate the historical literacy of students through the biographies of Buya Hamka. The method used is descriptive method. Historical literacy skills contributed to the gradual change in behavior towards the better for the children in Bayang.
\end{abstract}

Keywords: Historical Literacy, Biography, Creative Pedagogy, Character, Covid-19 


\section{INTRODUCTION}

Literacy is an important ability that must be possessed by students in order to realize the success of education in the 21 st century. The Covid-19 pandemic has its own shock for the indonesian education world, the house is transformed into a school so that it is needed to strengthen literacy and character to realize the golden generation of 2045. Indonesia must be more technologically literate especially in the pandemic that requires the learning process using digital technology not only schools in urban areas but also to rural areas. Literacy and character become a whole unit to score a superior generation of Indonesia both in terms of intellectual and form a dignified person so that it can benefit the surrounding community.

The government has been paying attention to the culture of literacy in order to establish quality human resources in accordance with the demands of revolution 4.0. Literacy must be cultivated early so that the public has awareness and has a high spirit of literacy because literacy is a fundamental thing in order to form a quality person. The School Literacy Movement (GLS) is one of the government programs that emphasizes the importance of building a culture of literacy in the world of education in order to realize generations and literate communities. The results of a 2016 survey by Central Connecticut State University (CCSU) stated that Indonesia's literacy ranking was ranked 60 th out of 61 countries just one level above Botswana [4]. Historical disciplines are actually built with writing and reading activities [19]. One part of literacy is historical literacy. According to Nokes (2011) historical literacy not only equips learners with knowledge of the facts of the past, but is also taught a set of skills in reading, writing, and providing arguments about historical evidence [15]. The National Historical Literacy Community was formed on July 10,2015 by the Association of Environmental Care Families (KERLIP) together with partners in the Smart Indonesia Movement as an effort to shape the character of the nation based on Indonesia's own history [16].

Historical learning has an important role to build the character of society supported by materials that contain important values for students. Character education can be integrated into history subject matter and learning process. In line with Sukarno's statement related to The Nation and Character Building, Ellen G. White stated that character building is a very important thing that must be given to humans. The correct purpose of education is to form students who are intellectually intelligent and have the character "Intelligence plus character, that is the true education" [12].

Electronic education and electronic learning through the internet are needed and realized in the learning system due to the pandemic situation so that historical learning must be able to adapt to the current conditions. Today's young generation is beginning to forget history along with the rapid development of globalization and ICT. Globalization is highly exalted but locality is like being forgotten, They animate the present but forget even weaken the past. The younger generation is an asset of the nation, a nation / country will be destroyed if the younger generation forgets its identity. This can be proven by the low knowledge of students about history even the younger generation is now much more familiar with influencers, youtubers and the like than the figures who play a role in building Indonesia. Freedom in accessing anything on the internet and expression on social media in accordance with the rapid development of ICT is not used for things that smell positive. In fact, Indonesia as one of the highest consumer countries using gadgets is still very lacking in improving literacy culture, especially historical literacy.

Strengthening character education can be achieved if there is pedagogy that can support it, namely through creative pedagogy because creativity becomes one of the five main elements of character education, namely religious, nationalist, integrity, mutual and independent. Creative pedagogy is a must to be developed in learning to face the challenges of the century. In the NAACCE (1999) it was stated that creative achievements always come from the ideas or creative experiences of others through books, theories, literature, poetry, stories and biographies. The realization of creative action can be through the use of character biographies to build the historical literacy skills of learners in order to strengthen character education because the challenges of the 21 st century faced by the world of education is very complex, education not only aims to equip learners with scientific thinking skills but also apply their character [13]. Many approaches that can be used to support character education include through strengthening character education (PPK) which is part of President Joko Widodo-Jusuf Kalla' Nawacita 
Program. Character Education strengthening movement serves to create situations, conditions and cultures that are conducive in applying the main values of character applied in the worl of education for both students and teachers. The main values that are strengthened in the application of strengthening character educaion are as follows religious, nationalist, independent, mutual cooperation and integrity.

Various character problems that make Indonesia experiencing multidimensional crises such as corruption, free association, student brawls, drugs, bullying, murders committed by teenagers such as murders committed by elementary school students against toddlers even in this pandemic the character of the younger generation is increasingly declining, students should have independence in literacy with an environment that demands digital but students are more creative on tik -tok that tends to be just entertainment and various indecent cases that occur during online learning such as the emergence of cases the effects of free association recorded accidentally during the learning or discipline of students are decreasing and disrespectful attitudes such as turning off the zoom video so that it can be other activities that signify the deterioration of the character of the nation's children.

Related to character problems, the same thing also happens among the children of Bayang, South Coast. Pandemic has changed the learning process including the habits of children in this area, Rural life that at first still reflects the incompetence of children in the digital world with the outbreak of the Covid-19 pandemic changed drastically where children who are supported by the learning process is virtually new to technology so that the use of technology becomes a new habit in their current environment but the author sees children only know but not technologically literate so do not understand to use technology well. Environmental conditions in bayang area, South Coast which is still lacking technology and still very constrained by signals make children carry out the learning process to gather in a place that has good network access for virtual learning considering this area is still very far from urban so there is no excessive concern about Covid-19 interactions that take place just between them in the village but the community can not be said to be ignorant of the pandemic, people in this area remain aware of the pandemic by limiting and checking if anyone comes to their area such as people who come from overseas and are stressed to do self-isolation first before it is completely declared not infected with corona virus in order to gather with their relatives. This is why children are free to gather both from elementary, junior high, junior high and even higher education to both have good internet access for the sake of continuity of the online learning process.

Based on the observations the authors made, the authors saw that with virtual learning and schools implementing shift systems, children in this area spend more time at home for games and accessing various other social media, this is evidenced by most teenage boys who gather together to access online games even late at night especially when they do not get shifts for face-to-face learning at school, In addition, the author also observes profanity and tends to be unethical when they communicate with each other and also see how the role of parents who should act more in this pandemic era considering their children are addicted to games and accessing other social media. The new habits that they live when new to technology are not even used for good literacy but more creative on creativity that does not give a positive impact such as tik-tok and moreover due to gaming addiction that is increasingly rampant in this pandemic era. This story is not a thumbs up but is a personal experience of the author so that the author has the idea that the place of association they call pondok mojok converted into a literacy hut because the strengthening of literacy and character is a shared responsibility especially for rural school children who have their own shock to digital technology if not given a good understanding in the application will lead to a decrease in the moral value of students.

\section{METHODS}

This research is qualitative research using descriptive methods. According to Cresswell (2008) qualitative research is an approach used to explore and understand central symptoms by conducting document analysis, direct observation and interviews [2]. This study describes the steps of activities that will be carried out in order to have a direct impact on the subject of the study. This research focuses on looking at the role of historical literacy through character biographies to strengthen the character education of the younger generation. This research was conducted on 20 children 
from the Bayang area, Pesisir Selatan, West Sumatera.

\section{A. Motivational Literacy}

The first activity that will be done is to provide motivation and understanding about the importance of literacy for the younger generation and other things that will provide attractiveness in order to increase the spirit of literacy in each of them.

B. Understanding of Historical Literacy

Provide children with understanding of historical literacy.

C. The Presentation of Historical Figures

This activity is continued by providing motivation related to the literacy of the values of character transparency. Figures are focused on figures from their own region, namely West Sumatra such as Bung Hatta and Buya Hamka.

\section{Group Division}

This activity is carried out by group division. The application of FGD method, then read his writing in front of his friends.

E. Assessment.

Researchers provide values and ratings so that children have a competitive spirit so that learning becomes interesting.

F. Reward

Indicators of success are improvements and improvement of students' character in a better direction while the evaluation will continue because the review of the character education process requires a long time and process and optimal work continuously in order to get maximum results.

Indicators of success are improvements and improvement of students' character in a better direction while the evaluation will continue because the review of the character education process requires a long time and process and optimal work continuously in order to get maximum results.

\section{RESULT AND DISCUSSION}

The National Institute for Literacy defines literacy as an individual's ability to read, write, speak, calculate, and solve problems at the level of expertise required in work, family and society. The Literacy and Numeracy Secretariat (2009) affirms that literacy will be able to form a critical society and help prepare a person to live in a knowledgeable society. According to Ahonan considers historical literacy to be a skill in reading and discussing history, If one is able to question historical evidence and explanations, then the person is considered to have understood the basic concepts of history as he stated that:

\begin{abstract}
Historical literacy' is a behaviouristic term suggesting a mastery of the basic historical information, which enables historical reading and discussion. If the person can ask questions of evidence and explanation, he or she is assumed to have a grasp of the basic procedural concepts of history and to be a critical reader $[1]$.
\end{abstract}

Character education is the most urgent problem in Indonesia By looking at the current educational situation becomes the main motivation (mainstreaming) for the implementation of character education because the implementation of character education is still considered less. According to Lickona, character is related to the concept of moral (moral knowing), moral attitude (moral feeling), and moral behavior Character can be formed through these three components, namely a person's knowledge of goodness, desire to do good, and do good deeds [10]. Character values are very attached to historical figures that can be used as material to explain material related to the values of the existence of figures for the strengthening of the education of the younger generation, such as the historical figure Buya Hamka

This figure comes from west Sumatra so as to provide its own attraction for children that in their own area there are hero figures who can be a motivation in each of them to lead a better life. Haji Abdul Malik Karim Amrullah, he is familiarly called Buya Hamka was born on February 17, 1908 in Maninjau, West Sumatra. Hamka obtained the title of Doctor Honoris 
Causa from Al-Azhar University and Prof. Moestopo University, this religious figure died on Friday, July 24, 1981. Hamka is better known as a cleric, he has initiated about moral education. Moral education from Hamka's perspective is very relevant to today's education, especially character education. Buya Hamka is very self-taught. He only learned basic religious lessons in his family environment, after which Buya Hamka sought experience and then developed it himself. Hamka equipped himself with knowledge by exploring java in 1924, especially Yogyakarta and Pekalongan [14]. Hamka then returned to West Sumatra in 1933, in 1936 he left for Medan to issue an Islamic weekly that reached the peak of his pre-war omnipotence of "Community Guidelines". The magazine he led from 1936 to 1943 , when the army entered Indonesia. So in those years hamka books were published from various fields [3]. In line with the statement of Andries Teeuw, professor of Leiden University as quoted by Sides Sudyarto, Hamka is an Indonesian roman author who produced many writings on Islam and has produced several literary works [17]. In addition to writing romance Hamka also poured his thoughts on the love of the homeland (nationalism) and the struggle to defend it contained in the work titled "From the valley of the mind". Hamka reflects his specialty as a spirit who is always productive wherever he is. Hamka's thoughts are not only cheerful but can inspire anyone who knows him. It is this fact that drives an argument that Hamka is not only a person who is able to leave teaching, but his mind is also the object of study from various points of view. For that reason, Syarif Maarif on an occasion stated, "Hamka is like a deep well that is clear water and will never be scanned by anyone. The more ditimba, the more we understand that this well water is sourced far in the world, there have been many theses and dissertations on Hamka reviewed by several researchers [11].

Howart Federspiel, as quoted by Muktaruddin stated hamka was a very influential figure who opened new insights and dynamics for minangkabau people. Despite a number of criticisms made over the credibility, capacity and quality of a Hamka never fades. Azyumardi Azra as one of the historians and thinkers of contemporary Indonesian Muslims stated that this will not reduce his phenomenal position and role in the development of Post-independence Indonesian Islam. [13]. Hamka is a person who is polite in advising his son, he asked permission first to his son before being given advice. As written by Irfan Hamka one of the most touching scenes is when Irfan Hamka says his father never scolded him harshly even to advise his children Hamka asked permission first. "Son, you want to advise you, will you listen?"

Hamka's patience was also reflected when facing slander from Pramodya Ananta Toer, when he wanted to marry his son to a young man of different religions, Pram ordered his future son-in-law to study Islam to Hamka. So big hearted Buya Hamka he was happy to teach pram's son and future son-in-law about Islam, even Hamka also who immersed pram's future son-in-law directly even though Pram's slander is quite cruel and everyone knows how Pram's writings in the mass media and newspapers are very mocking and defamatory hamka. Similarly, Sukarno imprisoned Hamka in prison without trial, alleging that Hamka would commit treason against him. However, when Sukarno was removed from power, Sukarno asked when he died to be prayed for by Hamka. Hamka with sincerity, fulfilled Sukarno's final request and led and accompanied Sukarno to his final resting place.

Furthermore, M. Yamin, he who always ridiculed Hamka as Buya who did not understand religion, even always opposed Hamka's statement openly with harsh words.Hamka never replied, even just replied with a smile. However, at the end of his life Yamin realized his own mistakes, he pleaded with Hamka to become the imam of his body prayers later, not only that, Yamin also asked Hamka to take his body home, Sawah Lunto. Again, with sincerity Hamka obeyed the wishes of the people who had wrongedi him. A very remarkable character, which is hard to find in this day and age [7].

The implementation of research conducted on children in Bayang, Pesisir Selatan, West Sumatra went well and got quite satisfactory results. The results showed that there is a pattern of changes in the behavior of children in Bayang area in a better direction gradually after conducting research focused on improving the ability of historical literacy through Buya Hamka biography that contributes to the strengthening of character education. Some indicators focus on the 5 main values of strengthening character education that serve to see the extent to which Buya Hamka's biography can contribute to the strengthening of 
the character of Bayang children by improving their historical literacy skills through the biography. The results can be seen in the indicator table below.

Table

\begin{tabular}{|c|c|c|c|}
\hline Number & $\begin{array}{c}\text { Primary } \\
\text { Values }\end{array}$ & Implementation & Results \\
\hline 1 & Religious & $\begin{array}{l}\text { Have the awareness to stop all activities when } \\
\text { entering the prayer time } \\
\text { - Start praying in the nearest village Mushola } \\
\text { Getting used to being honest with parents about } \\
\text { the activities carried out in mojok huts } \\
\text { - Abusive words in interacting with peers have } \\
\text { been reduced } \\
\text { - Didn't come home too late } \\
\text { - Honest in the division of group discussion tasks }\end{array}$ & $80 \%$ \\
\hline 2 & Nationalist & $\begin{array}{l}\text { - Have a passion for excellence in the young } \\
\text { generation of quality } \\
\text { - Have the awareness to be a superior person } \\
\text { - Start getting used to having the spirit of literacy } \\
\text { and getting to know the nation's heroes } \\
\text { Maintaining cultural wealth starts from the } \\
\text { richness of the surrounding culture, one of which } \\
\text { is the tradition of consensus / deliberation in } \\
\text { minangkabau ethnic culture. As the saying goes } \\
\text { Minangkabau "Bulek Aia dek Pambuluah, Bulek } \\
\text { Kato dek Mufakek" } \\
\text { Mutual respect for each other's opinions in group } \\
\text { discussions }\end{array}$ & $80 \%$ \\
\hline 3 & Independent & $\begin{array}{l}\text { - Show good performance in discussing } \\
\text { - Responsible for every task assigned in a group } \\
\text { Creative in thinking and acting } \\
\text { Start reviving the habits of rural children with } \\
\text { creative habits in helping income such as fishing } \\
\text { in the river, gardening, helping in calming and } \\
\text { rice fields when free time was previously } \\
\text { replaced by social media and games. }\end{array}$ & $80 \%$ \\
\hline 4 & $\begin{array}{c}\text { Mutual } \\
\text { Cooperation }\end{array}$ & $\begin{array}{l}\text { Work together in finding resources for } \\
\text { discussion activities. } \\
\text { - Decide the outcome of discussions with } \\
\text { deliberations and consensus } \\
\text { - Showing a helpful attitude as evidenced by } \\
\text { cleaning the cottage area mojok from strewn } \\
\text { garbage } \\
\text { - Solidarity helps agricultural activities around the }\end{array}$ & $80 \%$ \\
\hline
\end{tabular}




\begin{tabular}{|l|l|l|c|}
\hline & & \multicolumn{1}{|l|}{ location of mojok huts } & \\
\hline 5 & Integriity & $\bullet \begin{array}{l}\text { Honest in acting on tasks that have been divided } \\
\text { for discussion activities }\end{array}$ & $80 \%$ \\
& & $\begin{array}{l}\text { Responsible } \\
\text { Able to appreciate the opinions of friends in } \\
\text { discussing }\end{array}$ & \\
\hline
\end{tabular}

From the results presented in the indicator table explained that the implementation of improved historical literacy skills through the biography of Buya Hamka figures has been successful and goes well for the improvement and strengthening of the character of learners, especially rural children in bayang area, South Coast, West Sumatra. However, optimal and continuous work is still needed for the improvement and strengthening of the character in order to get maximum results.

\section{CONCLUSION}

Character problems are very prevalent in Indonesia making character problems are urgent problems that must be addressed immediately. History as a subject that is full of values is very closely related to the character of one of them through historical literacy. Historical literacy through events and the existence of figures will contribute to the strengthening of the character education of students because literacy will not only make students good at writing, reading but also help students to provide critical arguments against historical evidence only through learning the history of students not only understand the past but can realize the formation of identity as citizens.

Historical literacy as part of literacy has an important role to provide strengthening character education through the existence of historical figures so that attention is needed from all circles to improve the character of the younger generation in a better direction in order to realize the golden generation in 2045. This is done in the children of Bayang, Pesisir Selatan, West Sumatra by telling the existence of figures from their own region, namely Buya Hamka which makes children motivated and passionate in listening to the values of civility of the told figures that contribute to the formation of good characters gradually to the children because it is needed for the progress of a nation not only intelligent people but also have a good character so that it can be useful for the surrounding community.

\section{ACKNOWLEDGMENT}

This article is supported by Prof. Dr. Nana Supriatna M.Ed. Because he has provided suggestions so that the authoress can complete this article.

\section{REFERENCES}

[1] Ahonan, S. (2009). Historical Conciousness: A Viable Paradigm For History Education? Journal of Curriculum Studies.

[2] Creswell, John W. (2008). Research Design dan Mixed Pendekatan Kualitatif, Kuantitatif . Yogyakarta: Pustaka Pelajar.

[3] Damami, Mohammad, (2000). Tasawuf Positif dalam Pemikiran Hamka. Yogyakarta: Fajar Pustaka Baru.

[4] Damarjati, D. (2019). Benarkah Minat Baca Orang Indonesia Serendah Ini?. Detiknews, Retrieved from https://news.detic.com/berita.

[5] Garvey, Brian \& Krug Mary. (2015). Model-Model Pembelajaran Sejarah di Sekolah Menengah. Yogyakarta: Ombak.

[6] Gazalba, S. (1981). Pengantar Sejarah Sebagai Ilmu. Jakarta: Bharata Karya Aksara.

[7] Hamka, Rusyidi, (2016). Pribadi dan Martabat Buya Hamka, Jakarta: Noura.

[8] Hastuti, Hera. \& Zafri. (2019). "Literasi Sejarah Sebagai Upaya Penanaman Karakter Bagi Anak" Jurnal Diakronika, $19(2 \quad)$, 133-148.

[9] Irfan, H. (2013). Ayah. Jakarta: Republika Penerbit

[10] Lickona, T. (1991). An Integrated Approach to Character Development in the Elementary School Classroom. Moral Character and civic education, 67-83 
[11] Maarif, Ahmad Syafii, 2016, "Karya James R Rush tentang Hamka", dalam Re-publika,

[12] Marheni, Afrizal. \& Purnomo (2020). Applicaton of Character Building With Physical

[13] Muktaruddin. 2011. Idealisme Pendidikan Islam Hamka: Telaah Terhadap Pemikiran dan Pembaharuan Pendidikan Islam Hamka, Tesis. Pekanbaru: PPS UIN Suska Riau.Education (CBPE). Jurnal Ilmiah Pengabdian Kepada Masyarakat, 20(1), 46-53

[14] Nasihuddin, M, 2016, "Percikan Pemikiran Pendidikan Hamka", Jurnal Al Lu-bab 1(1), 166-180.

[15] Nokes, D. Jeffrey (2011). Historical Literacy. Historical Literacy-pdf.

[16] Sri Yulianti, Y. (2017). Keluarga Peduli Pendidikan (KERLIP), Menggiatkan Literasi Sejarah Bangsa dengan Merintis Komunitas Literasi Sejarah Bangsa (KOLASE). Berita satu.

[17] Sudyarto DS, Sides, 1996, "Hamka, Realisme Religius", dalam Nasir Tamara, dkk (Peny.), Hamka di Mata Hati Umat, 137-154. Jakarta: Pustaka

[18] Supriatna, Nana \& Maulidah, Neni. (2020). Pedagogi Kreatif. Bandung.

[19] Wineburg, S. \& Reisman, (2015).

Disciplinary literacy in history: A toolkit for digital citizenship. Journal of \& Adult Literacy58(8).663-669.

Adolescent 